\title{
GROWTH PERFORMANCE, SERUM BIOCHEMISTRY AND HAEMATOLOGICAL RESPONSE OF BROILERS CHICKEN EXPOSED TO NEEM (Azadirachta indica) AND ALOE VERA (Aloe barbadensis) LEAF EXTRACTS
}

\author{
Ogbu, U. ${ }^{* 1}$ Oladunjoye, R. Y. ${ }^{2}$ Okorafor, U.P. ${ }^{2}$ Unigwe, C.R. ${ }^{2}$ Odah, S.I. ${ }^{2}$ \\ ${ }^{* 1}$ Department of science laboratory technology, Federal College of Animal Health and Production Technology, Ibadan, Nigeria. \\ ${ }^{2}$ Department of Zoology and Environmental Biology, Olabisi Onabanjo University, Ago - Iwoye, Nigeria. \\ ${ }^{2}$ Federal College of Animal Health and Production Technology, Ibadan, Nigeria. \\ Phone: +234-08034393773, Email: ogbu.markson@gmail.com
}

DOI: $10.31364 / S C I R J / v 7 . i 3.2019 . P 0319622$

http://dx.doi.org/10.31364/SCIRJ/v7.i3.2019.P0319622

Abstract: Poultry production is gradually becoming a stable National economic development and as a protein source. The study explored the potential of $A$. indica leaf and A. barbadensis gel extracts as supplementary sources of vitamins and minerals in broiler growth performance, haematology and serum biochemistry. One hundred and fifty three (153) day old broiler birds were used. The birds of both sexes were randomly allotted into three treatment groups of 50 birds each, with each treatment replicated thrice in a Completely Randomized Design $(\mathrm{CRD}) ; \mathrm{T} 1=A$. indica leaf, $\mathrm{T} 2=A$. barbadensis gel extract and $\mathrm{T} 3=$ underground water. There were no significant differences ( $\mathrm{p}>0.05)$ in the initial weight of the birds. However, results showed that birds exposed to A. indica and A. barbadensis were significantly $(\mathrm{p}<0.05)$ different in final body weight and feed conversion ratio. A. indica had the lowest feed conversion ratio (2.29) than the other groups. There were significant differences $(\mathrm{p}<0.05)$ in the haematology and serum biochemistry of birds tested for in all the groups. This showed that the level of A. indica and A. barbadensis gel extracts enhanced the growth performance of broiler birds.

Key Words: Broiler chicken, Growth performance, Azadiracta indica and Aloe barbadensis

\section{INTRODUCTION}

Food insecurity and hunger has become a worldwide challenge in developing countries such as Nigeria which has continuing receiving attention from experts and governments (FAO, 2010; Emaikwu et al., 2011). Consequently, several summits on human nutrition eradicate the chanllenges of poverty and hunger (FAO, 1995) through animal protein supply has been held. In Nigeria, the major source of animal protein is through livestock industry which poultry production constitutes an important component. 
The word "poultry" is applicable to chicken or domestic fowl. The domestic fowl such as broilers, Cockrel, Layers, Noilers among others are avian species raised in the countries for either table meats or eggs or both for human consumption. Poultry production is one of the fastest means of achieving appreciable improvement in the nutritional standard of the populace because of its short generation interval, quick turnover rate and relatively low capital investment (Smith, 2001; Ani and Okeke, 2011).

In Nigeria, poultry industry would have improved more than its present status if performance, biochemical and haematologial response of the broiler chicken exposed to various leaf extracts are encouraged and monitored. The high cost and use of conventional commercial multivitamins to boost growth has already caused more harm than good to consumers. In view of this, the use of various plants extracts in broiler production has been documented. Broilers usually perform at low level and hence, production cost is higher and consequently selling prices of poultry products are higher beyond the reach of average Nigerians. Thus, per capital consumption of poultry products is lower in most tropical countries, thereby giving rise to protein deficiency factors in food in these countries since feed cost represent over $70 \%$ of the total cost of poultry production (Gerry et al., 2010).

The high cost of conventional feedstuff has already sent a lot of livestock farmers out of business, thus leading to reduction in overall animal protein production and availability for humans dietary's need. The provision of feed has been reported to account for $60-80 \%$ of total cost of livestock production in developing countries alone (Igboeli, 2000; Esonu, 2006). In view of this, there is increased interest by poultry farmers on the search for non-conventional feed ingredients that could be cheaper such as leaf and seed meals of ethno medicinal plants (Okoli et al., 2001). The use of various plant extracts in broiler production has been documented (Essien et al., 2007; Nworgu et al., 2007; Galib and Noor, 2010).

Water is the most important nutrient for the overall health and performance of commercial broilers. It plays an essential role in every aspect of metabolism and is critical to the regulation of the bird's body temperature, food digestion, and waste elimination (Lacy, 2002). By weight, broilers consume almost twice as much water as feed (Lacy, 2002). An adequate water supply is important to ensure that enough water is actually available to your birds. Low water flow rates can decrease flock performance (Lott et al., 2003). As long as water temperature is below body temperature, the bird receives some benefit from drinking because it helps with heat dissipation and body temperature regulation (Jones and Watkins, 2009).

Antibiotic growth promoters have been helpful in improvement of growth performance and feed conversion ratio in poultry (Miles et al., 2006; Dibner and Buttin, 2002). However, constant treatment of poultry by antibiotic may result in residues of these substances in poultry products and bacteria resistance against treatments in human body. However, properties of herbs, such as antioxidant, antiviral, or immune modulator properties and their effects on performance and digestive health of birds cannot be ignored. 
Neem tree (Azadiracta indica), is a tropical evergreen tree with its plant parts such as fruits, seeds, leaves, bark and roots contain compounds with proven antiseptic, antiviral, antipyretic, anti-inflammatory, antiulcer and antifungal uses. It has great potential in the fields of pest management, environment protection and medicine (Kumar and Gupta, 2011). It grows on almost all types of soil including clay, saline and alkaline soil, but does well on black soils and deep well drained soil with good sub-soil water because of ability to neutralize acidic soils by a unique property of calcium mining (Hedge, 2009).

Aloe vera (Aloe barbadensis) is one of the semi-tropical house plant under lily family which has a long and illustrious history dating from biblical times. It is spiky, succulent, and perennial (Volger et al., 2010). The leaves are lanceolate, thick and fleshy with thorny edges and with color ranging from deep green to grey-green. Aloe vera is not only a natural healer; it's also a growth enhancer in poultry. Hearing that, one might think, it's too good to be true. Essentially, the leaves of aloe vera are often for external uses only, they are not meant to be taken in. But with the study of (Bell and Weaver 2001), it's now clear that it's safe for animal intake. Thus, it is important to know what is in the aloe vera that makes it both a natural healer and a growth promoter in chickens.

Achieving maximum health and performance of poultry requires nutritionally balanced diets. One of the common issues with regard to back yard flocks relates to poor or inadequate feeding programs that can lead to vitamin and mineral deficiencies in the birds. Since vitamins and minerals are very important to normal physiological functioning of birds, inadequate supply of these nutrients will pose a serious problem to birds. It is also costly to use commercial produced vitamins hence increasing the cost of poultry production. The study aimed at determining the growth performance, haematological indices and serum biochemistry of broiler birds exposed to oral supplementation with aloe vera and neem leaf extracts as supplementary sources of vitamins and minerals to broiler birds.

\section{RESEARCH METHODOLOGY}

\section{Description of the Study Site}

The study was carried out at the Poultry Unit, Bora farm of the Federal College of Animal Health and Production Technology, Ibadan, Oyo State, Nigeria. The study lasted for a period of eight weeks; Two (2) weeks of acclimatization and six (6) weeks of exposure. The study area had the natural day-length of 13 to 14 hours; mean maximum weekly indoor and outdoor temperatures; of $27.9^{\circ} \mathrm{C}$ to $29.2^{\circ} \mathrm{C}$ and $26.8^{\circ} \mathrm{C}$ to $30.5^{\circ} \mathrm{C}$ respectively. The mean minimum weekly indoor and outdoor temperatures; $20.5^{\circ} \mathrm{C}$ to $22.3^{\circ} \mathrm{C}$ and $20.0^{\circ} \mathrm{C}$ and $23.6^{\circ} \mathrm{C}$ respectively, while relative humidity of $73.1 \%$ to $76.6 \%$ and mean monthly rainfall of $781.33 \mathrm{~mm}$ was recorded.

\section{Experimental Material Used}


The experimental birds were purchased from a reliable and hygienic source known as Agric-tech Nigeria limited, along Ife Odan Road, Awe, Oyo State. However, other materials such as Drinkers, Feeders, Brooms, Shovel, Bucket, Weighing scale, Wood shavings (bedding), Lamp, Disinfectants, Detergents, Coal pot, Measuring cylinder, Marker, Paper tape among others were sourced from the local markets around the farm.

\section{Experimental Birds and Management}

A total of One hundred and fifty three (153) 14-day old broiler birds were used for the experiment. The chicks were allowed to acclimatize in the farm for two weeks. The broiler chicks of both sexes were randomly allotted into three treatment groups of 51 birds each in a completely randomized design (CRD). The treatments were as follows: $T_{1}=$ Neem, $T_{2}=$ Aloe vera, $T_{3}=$ water. Each treatment was replicated three times with 17 chicks per replicate placed in a deep-litter pen of fresh wood shavings measuring $1.50 \mathrm{~m}$ x 1.50m. All the groups were fed with the same broiler starter diet containing 29.0/kg ME and 22\% crude protein.

The proximate composition of commercial feed used includes: crude protein (22.00\%), Fat/oil (6.00), crude fibre (5.00\%), Calcium (1.00\%), Available Phosphorus (0.45), Lysine (1.20), Methionine (0.55), Salt (0.30), Energy (29.00Kcal/KgME), Net weight $(25 \mathrm{Kg})$. Routine management practices in terms of medication and vaccination were strictly observed. Birds were fed two times a day with the test material. Neem and Aloe vera extracts were given to the birds for 6 weeks.

Birds in each replicate were weighed using weighing scale at the beginning of the experiment and subsequently on weekly basis to determine the weight gain or loss in each bird. Feed intake was also recorded weekly and was determined by the weigh-back technique, which involved obtaining the difference between quantity of feed offered and the left-over in the following morning. Feed conversion ratio was calculated from the data on feed intake and weight gain as the number of grams of feed consumed per gram of weight gained over the period of time.

\section{Sample Collection/Preparation}

\section{Preparation of Aloe Vera Gel Extract}

Fresh Aloe-vera (A. barbadensis) leaves were collected from the botanical garden of federal college of animal health and production technology Apata Ibadan, Oyo State, Nigeria. The leaves were washed with clean water to remove any physical dirt and weighed. Care was taking not to tear the green rind that can contaminate the fillet with leaf exudates. A traditional hand filleting method of processing Aloe barbadensis leaf was used. In this method, the lower leaf base, the tapering point at the leaf top and the short spines located along the long margins are removed by sharp blades. The blade is then introduced into the mucilage layer below the green rind avoiding the vascular bundles, and the top rind was removed. The epidermis of the leaves was peeled off, and the parenchymatous tissue was collected. The colorless, solid mucilaginous gel was cut into piece and ground. It was then packed into soxhlet apparatus for extraction and 2 litres of the solution served fresh to the animals (Mandrioli et al 2011). 


\section{Preparation of Azadirachta indica Leaf Extract}

Fresh matured Neem (A. indica) leaves were collected from the botanical garden of the Federal College of Animal Health and Production Technology, Ibadan, Oyo State, Nigeria and washed with a clean water to remove any dirt. The leaves were mash with mortar and pestle. It was then packed into a container and clean water added to it, the extract is filtered to avoid residue and allowed to stand for $24 \mathrm{hrs}$ under laboratory condition and 2 litres of the solution was served to the animals in each of the treatment.

\section{Haematology and Serum Analysis}

The parameters measured are body weight, feed intake and water intake, while weight gain, feed conversion ratio and water intake were calculated. Meanwhile, apparent nutrient retention was determined. At the eight (8) weeks of the experiment, three birds per treatment were randomly selected and blood samples were collected from the wing veins of each bird using sterilized syringe and emptied into an EDTA (Ethylene diaminetetracetic acid) bottles for haematological analysis.

Haematological parameters that were determined included Haemoglobin Concentration (HbC), Packed Cell Volume (PCV), White Blood Cell (WBC) count, and Red Blood Cell (RBC) count. The PCV was determined by the microhaematocrit method described by (Schalm et al., 1975), and (Mitruka and Rawnsely, 1977) using a microhaematocrit centrifuge and reader (Hawksley and Sons Ltd, England). The HbC was determined using a haemoglobinometer (Marienfeld, Germany), while the WBC counts were carried out by the haemocytometer method using an improved Neubauer counting chamber (Hawksley, England) and avian RBC and WBC diluting fluids as described by (Campbell and Coles, 1986) and (Lamb, 1991).

Serum metabolites such as Total Protein (TP), Glucose Albumin, Globulin, Creatine, Cholesterol and Calcium were determined according to the standard methods described by (Campbell and Coles, 1986).

\section{Statistical Analysis}

A two way analysis of variance (ANOVA) for completely randomized design (CRD) was employed to determine whether there were significant differences in variables measured among the experimental groups using statistical package for social sciences (SPSS) (version 20.0). Significantly different means were separated using Duncan's Multiple Range Test (DMRT) (Duncan, 1995) option in SPSS where $\mathrm{P}<0.05$ was accepted that the treatment means were significantly different.

\section{RESULTS AND DISCUSSION}

\section{Proximate Composition of Aloe barbadensis Gel and Azadirachta indica Leaf Extract}

The proximate composition of Aloe barbadensis gel and Azadirachta indica leaf extracts was presented in Table 1 and 2 respectively. The Crude protein $20.02 \%$ value obtained in this study was higher than the Crude protein value of $6.86 \%$ reported by 
(Muaz et al., 2013) Chemical Composition and Biochemical Activity of Aloe vera (Aloe barbadensis) Leaves . However, the same authors have also reported Crude fibre level of $73.35 \%$, Ash 16.88 for Aloe vera leaf extract, which is also higher compared to the Crude fibre $10.00 \%$ and Ash $8.99 \%$ observed in this present study. However the proximate composition of the present study was higher than that reported by Adesuyi et al. (2012) Nutritional and Phytochemical Screening of Aloe barbadensis. The same author reported Ether extract $2.91 \%$, Ash 2.36, Crude protein 4.73 and Crude fibre $7.84 \%$ respectively.

Table 1: Proximate Composition of Aloe barbadensis leaf Extracts

\begin{tabular}{lc}
\hline Nutrient & Dry Matter (\%) \\
\hline Dry matter & 44.06 \\
Crude fibre & 10.00 \\
Ether extract & 4.40 \\
Crude protein & 20.02 \\
Ash & 8.99 \\
Nitrogen-free extract & 0.65 \\
\hline
\end{tabular}

Table 2: Proximate Composition of Azadirachta indica Leaf Extract

\begin{tabular}{ll}
\hline Nutrient & Dry Matter (\%) \\
\hline Dry matter & 81.65 \\
Crude fibre & 11.35 \\
Ether extract & 7.07 \\
Crude protein & 18.00 \\
Ash & 6.60 \\
Nitrogen-free extract & 36.63
\end{tabular}

The differences in the Crude protein and Crude fibre in the present findings may be related to the ages of the leaf used. It is established that aged leaves reduces the Crude protein while the Crude fibre content increases (Onyimonyi et al., 2009).

Proximate composition of $A$. indica leaves result is presented in Table 2. The result obtain is lower than the findings reported by (Onyimonyi et al., 2009). Crude fibre level of $11.35 \%$, ash $6.60 \%$, Ether extract $7.0 \%$ and Nitrogen free extract $36.63 \%$ for the $A$. 
indica leaf while (Onyimonyi et al., 2009) reported Crude fibre level of $12.00 \%$, ash $7.00 \%$, Ether extract $6.00 \%$ and Nitrogen free extract 51.94 for the A. indica leaf.

\section{Qualitative Analysis of Azadirachta indica and Aloe-barbadensis Aqueous Extract}

The qualitative analysis of Azadirachta indica and Aloe barbadensis leaf extract was presented in Table 3. Alkaloids, Carbohydrate, Tannins and Flavonoids are present in both leaves extracts, while Glycoside and Saponins are absent in both leaves extracts (Table 3). Meanwhile, Protein and Phenolic Compounds are present in Azadirachta indica leaf but absent in Aloe barbadensis extracts.

The growth performance of broilers chicken exposed to oral supplementation with Azadirachta indica leaf and Aloe barbadensis gel extracts was represented in Table 4 . There was a significant difference $(\mathrm{P}<0.05)$ observed in all the treatments. The effect of increase in final body weight (FBW) observed in $\mathrm{T}_{1}$ (Azadirachta indica) can be attributed to the antimicrobial properties of Azadirachta indica which might aid the reduction in the harmful microorganisms in the intestine of the birds thereby increasing absorption of digested feeds. Similar suggestions have been made by (Esonu et al., 2006 and Onyimonyi et al., 2009).

Table 3: Qualitative Analysis of Azadirachta indica and Aloe-barbadensis leaf Extract

\begin{tabular}{lcc}
\hline Parameters & Azadirachta indica & Aloe barbadensis \\
\hline Alkaloids & + & + \\
Carbohydrate & + & + \\
Glycoside & - & - \\
Protein & + & - \\
Phenolic Compounds & + & - \\
Tannins & + & + \\
Flavonoids & + & + \\
Saponins & - & -
\end{tabular}

Table 4: Growth Performance of Broilers Chicken Exposed to Azadirachta indica and Aloe barbadensis Leaf Extract

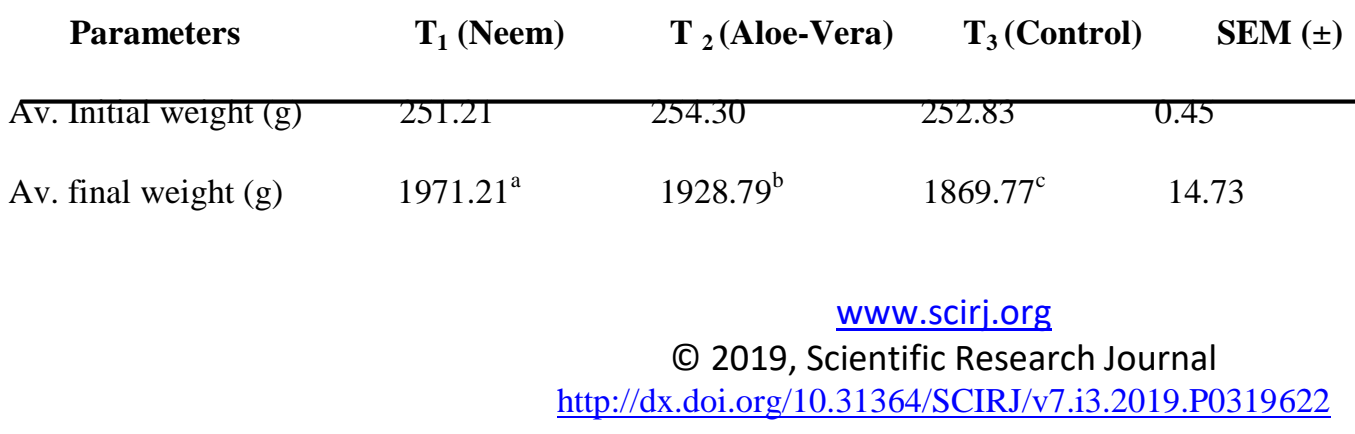




$\begin{array}{llllc}\text { Av. Total weight gain }(\mathrm{g}) & 1720.00^{\mathrm{a}} & 1674.49^{\mathrm{b}} & 1616.94^{\mathrm{c}} & 4.32 \\ \text { Av. Total feed intake (g) } & 3942.42^{\mathrm{a}} & 3930.30^{\mathrm{c}} & 3936.36^{\mathrm{b}} & 3.99 \\ \text { Av. Total water intake (ml) } & 10663.39^{\mathrm{a}} & 10562.64^{\mathrm{b}} & 10456.73^{\mathrm{c}} & 29.97 \\ \text { Feed Conversion Ratio } & 2.29^{\mathrm{c}} & 2.35^{\mathrm{b}} & 2.43^{\mathrm{a}} & 0.92\end{array}$

a,b,c Means on the same row with different superscripts are significantly $(\mathrm{P}<0.05)$ different. $\quad$ Keys:

SEM - Standard Error of the mean. $\mathrm{T}_{1}-\left(2 \mathrm{~g}\right.$ of Neem leaf extract +4 litres of water). $\mathrm{T}_{2}$ - (30ml of Aloe-Vera gel extract +4 litres of water). $\mathrm{T}_{3}$ - (Control). Av - Average. $\mathrm{T}_{1}, \mathrm{~T}_{2}, \mathrm{~T}_{3}$ - Treatment one, two and three.

Several other studies have suggested additives, including herbs, as alternatives to antibiotics, with direct or indirect effects on intestinal microflora, in poultry products (Taylor, 2001). Also, antimicrobial properties of herb extracts (Cowan, 1999; Hammer et al., 1999) which can improve intestinal microflora population and enhance health in birds' digestive systems through reduction in number of disease making bacteria have been reported (Mitsch et al., 2004).

In addition, modified harmful microbial population in intestines will change intestinal morphology. Intestinal health is of great importance in poultry for improved performance and reduced feed conversion ratio (Montagne et al., 2003). However the feed conversion ratio (FCR) of the three treatments $\mathrm{T}_{1}-\mathrm{T}_{3}$ recorded to be 2.29, 2.35 and 2.43 showed significant difference among groups. The Average Initial Weights (AIW) for $\mathrm{T}_{1}, \mathrm{~T}_{2}$ and $\mathrm{T}_{3}$ with the weight of $251.21 \mathrm{~g}, 254.30 \mathrm{~g}$ and $252.83 \mathrm{~g}$ showed a significant difference $(\mathrm{P}>0.05)$ among the three treatments.

The Average Final Body Weights (AFBW) of $\mathrm{T}_{1}-\mathrm{T}_{3}$ was $1971.21 \mathrm{~g}, 1928.79 \mathrm{~g}$ and $1869.77 \mathrm{~g}$ which showed a significant difference $(\mathrm{P}<0.05)$ among the treatments. The Average Total Weight Gain $(A T W G)$ of the three treatments; $\mathrm{T}_{1}-\mathrm{T}_{3}$ was $1720.00 \mathrm{~g}$, $1674.49 \mathrm{~g}$ and $1616.94 \mathrm{~g}$ respectively, showed a significant difference $(\mathrm{P}<0.05)$ among the treatments. The birds exposed to $\mathrm{T}_{1}(\mathrm{Neem})$ and $\mathrm{T}_{2}$ (Aloe vera) has higher weight gain compared to $\mathrm{T}_{3}$ control at the end of six week exposure. This finding was in agreement with the similar report by Guo et al. 2004; Jiang et al. 2005 and Durrani et al. 2008 findings.

The average feed intake of the three treatments $T_{1}-T_{3}$ was $3942.42,3930.30$ and 3936.36 which showed a significance difference $(\mathrm{P}<0.05)$ among the three groups. However, same thing is applied to average water intake of the three groups $\mathrm{T}_{1}-\mathrm{T}_{3}$ that was $10663.39,10562.64$ and 10456.73 with a significance difference $(\mathrm{P}<0.05)$ across the groups respectively. The Feed conversion ratio of the three groups of broilers exposed to ordinary water, Azadirachta indica and Aloe barbadensis showed a significantly difference $(\mathrm{P}>0.05)$ values for each treatment $\mathrm{T}_{1}(2.29), \mathrm{T}_{2}(2.35)$ and $\mathrm{T}_{3}(2.43)$ among the groups when compared.

The haematological indices of broiler chicken exposed to different concentrations of Azadirachta indica leaf and Aloe barbadensis gel extracts is shown in Table 5. Hematological parameters are good indicators of the physiological status of animal and its changes are of value in assessing the response of animals to various physiological situations (Esonu et al., 2006). 
This study showed a significant $(\mathrm{P}<0.05)$ difference in all haematological parameters which supports (Ojha et al., 2011) who stated that oral administration of Aloe barbadensis and Azadirachta indica extracts significantly increases or decreases the Rbc and $\mathrm{Hb}$ values when exposed. This showed that there is decline in haemoglobin and PCV concentrations with inclusion of Azadirachta indica and Aloe barbadensis leaves in the groups compared with standard level 35.9 - 41.0\% observed, was in line with (Ogbuewu et al., 2010) which showed that Azadirachta indica leaf meal have mild depressive effect on the haemoglobin concentration and PCV of female rabbits at various inclusion level.

The birds showed a mild depressive effect which indicates that these animals were slightly stressed with the research treatments. The Packed Cell Volume (PCV) level in $\mathrm{T}_{1}(16.07), \mathrm{T}_{2}(16.04)$ and $\mathrm{T}_{3}(15.70)$ showed a significance difference $(\mathrm{P}<0.05)$ among the groups. However, there was no difference $(\mathrm{P}>0.05)$ in $\mathrm{T}_{1}(16.04)$ and $\mathrm{T}_{2}(16.00)$ when compared. The Haemoglobin $(\mathrm{HB})$ of $\mathrm{T}_{1}$ (5.07), $\mathrm{T}_{2}(5.20)$ and $\mathrm{T}_{3}(4.70)$ showed a significance difference $(\mathrm{P}<0.05)$ among the three groups.

Table 5: Heamatological Indices of Broilers Chicken Exposed to Aloe barbadensis and Azadirachta indica Leaf extract

\begin{tabular}{lcccc} 
Parameters & $\mathbf{T}_{\mathbf{1}}($ Neem) & $\mathbf{T}_{2}$ (Aloe vera) & $\mathbf{T}_{3}$ (Control) & SEM \\
\hline PCV $(\%)$ & $16.07^{\mathrm{a}}$ & $16.04^{\mathrm{b}}$ & $15.00^{\mathrm{c}}$ & 0.16 \\
HB $(\mathrm{g} / \mathrm{dl})$ & $5.70^{\mathrm{a}}$ & $5.07^{\mathrm{b}}$ & $4.10^{\mathrm{c}}$ & 0.08 \\
RBC $\left(10^{6} / \mu \mathrm{l}\right)$ & $1.23^{\mathrm{a}}$ & $1.20^{\mathrm{b}}$ & $1.13^{\mathrm{c}}$ & 0.02 \\
WBC $\left(10^{3} / \mu \mathrm{l}\right)$ & $11.80^{\mathrm{a}}$ & $11.50^{\mathrm{b}}$ & $10.80^{\mathrm{c}}$ & 101.43 \\
Platelet $(\mu \mathrm{l})$ & $512001.00^{\mathrm{a}}$ & $132001.00^{\mathrm{c}}$ & $154001.00^{\mathrm{b}}$ & 19498.51 \\
Lymphpocyte $\left(10^{3} / \mathrm{mm}^{3}\right)$ & $47.00^{\mathrm{c}}$ & $54.01^{\mathrm{b}}$ & $57.00^{\mathrm{a}}$ & 1.48 \\
Heterophil (\%) & $43.00^{\mathrm{a}}$ & $38.01^{\mathrm{b}}$ & $35.00^{\mathrm{c}}$ & 1.67 \\
Monocyte $(\%)$ & $5.00^{\mathrm{a}}$ & $5.00^{\mathrm{a}}$ & $4.01^{\mathrm{b}}$ & 0.17 \\
Eosnophil $(\%)$ & $4.00^{\mathrm{a}}$ & $4.00^{\mathrm{a}}$ & $3.00^{\mathrm{b}}$ & 0.17 \\
Basophil $(\%)$ & $0.00^{\mathrm{b}}$ & $0.00^{\mathrm{b}}$ & $1.00^{\mathrm{a}}$ & 0.17 \\
\hline
\end{tabular}

${ }^{a, b, c}$ Means on the same row with different superscripts are significantly $(\mathrm{P}<0.05)$ different $\quad$ Keys;

SEM - Standard error of the mean. $\mu 1$ - microlitre. $\mathrm{mm}$ - milimetre. $\%$ - percentage.

g/dl - gram per deciliter. PCV - Packed Cell Volume. HB - Haemoglobin. RBC - Red Blood Cell. WBC - White Blood Cell. 
However, the Red Blood Cell (RBC) level among the three treatment $\mathrm{T}_{1}(1.13), \mathrm{T}_{2}(1.20)$ and $\mathrm{T}_{3}(1.32)$ showed a level of significance $(\mathrm{P}<0.05)$. The White Blood Cell (WBC) level of $\mathrm{T}_{1}(11.80), \mathrm{T}_{2}(11.50)$ and $\mathrm{T}_{3}(10.80)$ showed a level of significance $(\mathrm{P}<0.05)$ when compared to the three groups. The increase above normal range is an indication that the immune system is working to destroy an infection. The Platelets level of the three groups $\mathrm{T}_{1}(5.12), \mathrm{T}_{2}(1.32)$ and $\mathrm{T}_{3}(1.54)$ showed a level of significance $(\mathrm{P}<0.05)$ in the three groups. While Lymphocyte (LYM) level in the three groups $\mathrm{T}_{1}(57.00) \mathrm{T}_{2}(54.00)$ and $\mathrm{T}_{3}(47.00)$ showed level of significance $(\mathrm{P}<0.05)$ among the three groups.

Also, the Heterophil (HET) level in $\mathrm{T}_{1}$ (38.00), $\mathrm{T}_{2}(35.00)$ and $\mathrm{T}_{3}(43.00)$ showed level of significance $(\mathrm{P}<0.05)$ in the three groups. However, the Monocyte $(\mathrm{MON})$ also showed levels of significance $(\mathrm{P}<0.05)$ among the 3 groups but did not show any level of significance $(\mathrm{P}>0.05)$ between $\mathrm{T}_{1}(5.00)$ and $\mathrm{T}_{2}$ (5.00). This study showed traces of monocytes and eosinophils in all the broilers with the two treatments which were against the findings of Obikaonu et al. (2011) which reported no traces of monocytes, eosinophils and basophils in haematological analysis of broiler as suggested by Akpan (2007) findings.

The Eosinophil (EOS) level for broilers exposed to Azadirachta indica leaf extracts in $\mathrm{T}_{1}$ (4.00) and Aloe barbadensis gel extracts in $\mathrm{T}_{2}$ (4.00) showed no level of significant difference $(\mathrm{P}>0.05)$ between the two groups, but there was a significant difference $(\mathrm{P}<0.05)$ when comparing with $\mathrm{T}_{3}(3.00)$. Basophil (BASO) level showed no significant difference $(\mathrm{P}>0.05)$ between the groups $\mathrm{T}_{1}$ (0.00) and $\mathrm{T}_{2}(0.00)$. This findings conform with the earlier work of Obikaonu et al. (2011) that showed no trace of basophils seen in the control group as it is absent in the treatment containing Azadirachta indica and Aloe barbadensis leaves extract.

The serum biochemical indices of broilers chicken exposed to different concentration of Azadirachta indica leaf and Aloe barbadensis gel extracts is shown in Table 6.

Table 6: Serum Biochemical Indices of Broilers Chicken Exposed to Aloe barbadensis and Azadirachta indica Leaf extract

\begin{tabular}{lclll} 
Parameters & $\mathbf{T}_{\mathbf{1}}(\mathbf{N e e m})$ & $\mathbf{T}_{\mathbf{2}}$ (Aloe vera) & $\mathbf{T}_{\mathbf{3}}$ (Control) & SEM \\
\hline Total protein $(\mathrm{g} / \mathrm{dl})$ & $3.28^{\mathrm{b}}$ & $4.11^{\mathrm{a}}$ & $3.13^{\mathrm{c}}$ & 0.15 \\
Albumin $(\mathrm{g} / \mathrm{dl})$ & $0.50^{\mathrm{b}}$ & $0.80^{\mathrm{a}}$ & $0.51^{\mathrm{b}}$ & 0.50 \\
Globulin $(\mathrm{g} / \mathrm{dl})$ & $2.79^{\mathrm{b}}$ & $3.30^{\mathrm{a}}$ & $2.50^{\mathrm{c}}$ & 0.12 \\
Albulin/Globulin ratio $(\mathrm{g} / \mathrm{dl})$ & $0.10^{\mathrm{b}}$ & $0.20^{\mathrm{a}}$ & $0.21^{\mathrm{a}}$ & 0.02 \\
Aspartate $(\mu \mathrm{l})$ & $187.67^{\mathrm{b}}$ & $193.67^{\mathrm{a}}$ & $185.10^{\mathrm{c}}$ & 1.28 \\
$(\mu \mathrm{l})$ & $25.00^{\mathrm{b}}$ & $26.03^{\mathrm{a}}$ & $21.00^{\mathrm{c}}$ & 0.77 \\
Cholesterol $(\mathrm{mg} / \mathrm{dl})$ & $197.33^{\mathrm{a}}$ & $186.00^{\mathrm{b}}$ & $172.07^{\mathrm{c}}$ & 3.66 \\
$\mathrm{TMg}(\mathrm{mg} / \mathrm{dl})$ & $54.01^{\mathrm{c}}$ & $75.70^{\mathrm{a}}$ & $72.07^{\mathrm{b}}$ & 3.36
\end{tabular}



Total Bilurubin $(\mathrm{mg} / \mathrm{dl})$
$0.40^{\mathrm{a}}$
$0.31^{\mathrm{b}}$
$0.10^{\mathrm{c}}$
0.04

a, b,c Means on the same row with different superscripts are significantly $(\mathrm{P}<0.05)$ different $\quad$ Keys:

SEM - Standard error of the mean. $\mathrm{g} / \mathrm{dl}$ - gram per deciliter. $\mu \mathrm{l}$ - microlitre. $\mathrm{mg} / \mathrm{dl}$ -

milligram per deciliter. ALT - Alanine Aminotransferase. TMg - Total Magnesium

Serum biochemical test revealed significant difference $(\mathrm{P}<0.05)$ in most of the parameters of serum biochemical indices determined.

This finding was not in line with Mehala and Moorthy (2008) who reported that no significant difference among the treatment groups by dietary inclusion of Aloe-barbadensis and Curcuma longa and its combinations in broiler birds. Total protein in $\mathrm{T}_{1}(3.28), \mathrm{T}_{2}(4.11)$ and $\mathrm{T}_{3}(3.13)$ showed level of significance $(\mathrm{P}<0.05)$ among the three groups.

The Albumin level in $\mathrm{T}_{1}(0.49), \mathrm{T}_{2}(0.80)$ and $\mathrm{T}_{3}(0.50)$ showed significant level $(\mathrm{P}<0.05)$ on the three groups. The decreased level of protein and albumin level in the entire groups coincide with Mehala et al. (2008) findings. Serum albumin and globulin depend on availability of dietary protein depending on the dosage Mehala et al. (2008). The reduction in globulin in this study is also in support of Ogbuewu et al. (2010) who recorded the same reduction in administering Azadirachta indica leaves meal in rabbit diets.

Globulin level in $\mathrm{T}_{1}(0.10), \mathrm{T}_{2}(3.30)$ and $\mathrm{T}_{3}(2.50)$ showed a significant difference $(\mathrm{P}<0.05)$ among the treatment groups. Albumin/Globulin ratio in $\mathrm{T}_{1}(0.10), \mathrm{T}_{2}(0.20)$ and $\mathrm{T}_{3}(0.20)$ showed no significant difference $(\mathrm{P}>0.05)$ in all the treatments. The Aspertate level (AST) in $T_{1}(18.76), T_{2}(19.36)$ and $T_{3}(18.51)$ showed significant difference $(P<0.05)$ among the three groups and Alanine aminotransferase (ALT) level in $\mathrm{T}_{1}(25.00), \mathrm{T}_{2}(26.03)$ and $\mathrm{T}_{3}(21.00)$ showed a significant difference $(\mathrm{P}<0.05)$ among the groups.

The cholesterol level in $\mathrm{T}_{1}$ (197.33), $\mathrm{T}_{2}(186.00)$ and $\mathrm{T}_{3}(172.06)$ showed a level of significance $(\mathrm{P}<0.05)$ in the three groups. Furthermore, the significant difference observed in $\mathrm{T}_{1}, \mathrm{~T}_{2}$ and $\mathrm{T}_{3}$ in level of cholesterol conform to the findings of Mehala et al. (2008). However, the same applied to $\mathrm{TMg}$ level in $\mathrm{T}_{1}(5.40), \mathrm{T}_{2}$ (7.50) and $\mathrm{T}_{3}(7.50)$ that showed a significant difference $(\mathrm{P}<0.05)$ in the three treatments groups. Total Bilirubin level in $\mathrm{T}_{1}(0.40), \mathrm{T}_{2}(0.30)$ and $\mathrm{T}_{3}(0.10)$ also showed significant difference $(\mathrm{P}<0.05)$ among three treatments.

\section{CONCLUSION AND RECOMMENDATION}

Conclusively, Broiler chicks exposed to Aloe barbadensis and Azadirachta indica leaf extracts showed better performance in weights compared to the control groups. It is recommended that farmers adopt the use of Azadirachta indica leaf and Aloe barbadensis leaf extract in oral supplementation as an alternative to commercial vitamins sold in the market. 


\section{REFERENCES}

Adesuyi, O. A., Awosanya, A. O., Adaramola, F. B. and Omeonu, A. I. (2012). Nutritional and Phytochemical Screening of Aloe barbadensis. Research Journal of Biological Science 4(1): 4-9.

Akpan, M. J., Enyenihi, G. E., Obasi, O. L., Solomon, I. P. and Udedibie, A. B. (2007). Effects of dietary neem leaf extract on the

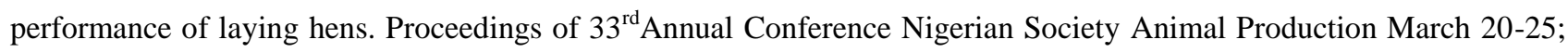
396-398.

AOAC. Association of Official Analytical Chemists. Official Methods of Analysis (21 $1^{\text {st }}$ edition)Washington D.C. USA 78.

Bell, D. D. and Weaver, W. D. (2001). Commercial chicken production. $5^{\text {th }}$ edition, Los Angeles, California, USA, Kluwer. Pp. 7587.

Campbell, T.W. and Coles, E. H. (1986). Avian clinical pathology. In: Coles E. H (ed)Veterinary Clinical Pathology.4th edn. Saunders, Philadelphia, pp. 279-291.

Chemistry indices of broiler chicken served fluted pumpkin (Telefaria occidentalis)leaves extract supplement. American-Eurasian Journal of Agriculture \& Environmental sciencies, 2(1):90-99.

Cowan, M. M. (1999). Plant products as antimicrobial agents. Clin. Microbiol. Rev. 12: 564-582.

Dibner, J. J. and Buttin, P. (2002). Use of organic acids as a model to study the impact of microflora on nutrition and metabolism. Journal Appl. Poultry Res. 11: 453-463.

Duncan, D. B. (1995). Multiple Range and Multiple F-test. Biometrics, 11:1-42.80.

Durrani, F. R., Sultan, A. M. Marri, L., Chand, N. and Durrani, Z. (2008). Effect of Wild Mint (Menthalongifolia) Infusion on the Overall Performance of Broiler Chicks. Pak. Journal Biology Science, 10(7): 1130-1133.

Emaikwu, K. K., Chikwendu, D. O. and Sanni, A. S. (2011). Determination of Flock size in Production in Kaduna State of Nigeria. Journal of Agricultural Extension and Rural $\quad$ Development, 3(1); 202-211.

Esonu, B. O., Opara, M. N., Okoli, I. C., Obikaonu, H. O., Udedibie, C. and Iheshiulor, O. M. (2006). Physiological responses of laying birds to Neem (Azadirachtaindica) leaf meal based diets, body weight, organ characteristics and hematology. Online Journal Health $\quad$ Allied Science, 2: 4.

Essien, J. P., Ebong, G. A. and Akpan, E. J. (2007). Antioxidant and Antitussive Properties of Gongronemalatifolium. Journal of Appl. Science Environment Management 11(4): 47-50.

Food and Agricultural Organization (1995). Utilization of Poultry Feed Resources by Small holders in villages in Developing Countries. 2(3): 34 .

Food and Agricultural Organization of the United Nations (2010). Rome, Italy. 
Galib, A. M. A and Noor, M. W (2010). Comparative study on diet supplementation with a mixture of herbal plants dandelion as a source of prebiotics on the performance of broilers. Pakistian Journal of Nutrition, 9(1): 67-71.

Gerry, A., Ernst, R., Jeffrey, J. and McCrea, A. (2010). Common Lies and Mites of Poultry: Identification and Treatment. University of California. Agriculture and Natural Resources. Pp. 205-225.

Guo, F. C., Kwakkel, R. P., Soede, J., Williams, B. A. and Verstegen, M.W. (2005). Effect of a Chinese herb medicine formulation, as an alternative for antibiotics, on performance of broilers. Britain Poultry Science, 45(6): 793-797.

Hegde, N. G. (2009). Neem production and development - constraints at grass root level. Pp. 59-67.

http//faosta.fao.orgPSN 2009. Poultry site News:http://'poultrynewsdesk.com. August, 2017.

Igboeli, G. (2000). Animal production and agriculture in the new millennium. Proceedings of the 25th Annual Conference of Animal science Production Nigeria, pp.1-3.

Kumar, R.V. and Gupta, V.K., (2011). Thrust on neem is need of today fibre and the intestinal mucosa, and their consequences on digestive health in young non ruminant animals. Animal Feed Science Techonology, 108:95-117.

Lacy, M. (2002). Broiler management: Commercial Chicken Meat and Egg Production Academic Pub. Pp. 829-868.

Lamb, G. N. (1991). Manual of Veterinary Laboratory Technique, kenya. Pp.92 - 109.

Lott, B. D., Dozier, W.A., Simmons, J.D. and Rouch, W.B. (2003). Water flow rates in commercial broiler houses. Poultry Science 82:102-106.

Mandrioli, R., Mercolini, L., Feranti, A., Fanalis, R., Raggi, M., (2011) Determination of aloe vera extract and neem formulations, food chem. 126:387-393.

Mehala, C. and Moorthy, M. (2008). Production Performance of Broilers Fed with Aloe vera and Curcuma longa (turmeric). International Journal of Poultry sciences, 7(91):852-856.

Miles, R. D., Butcher, G. D., Henry, P. R., Littell, R. C. (2006). Effect of antibiotic growth promoters on broiler performance, intestinal growth parameters, and quantitative morphology. Poultry Science, 85:476-485.

Mitruka, B. M., and Rawnsley, H. M. (1977). Clinical Biochemical and Haematological Reference Values in Normal Experimental Animals, Masson, New York. Pp. 42 - 45.

Mitsch, P., Zitterl-Eglseer, K., Kohler, B., Gabler, C., Losa, R., Zimpernik, I. (2004). The effect of two different blends of essential oil components on the proliferation of Clostridium perfringens in the intestines of broiler chickens. Poultry Science, $83: 669-675$.

Montagne, L., Pluske, J. R. and Hampson, D. J. (2003). A review of interactions between dietary Indian World Neem Conference Souvenir. ICAR, New Delhi, India. 121: 1040-1048 
Muaz, A. and Fatma, H. (2013).Chemical Composition and Biochemical Activity of Aloe vera (Aloe barbadensis Miller) Leaves.

IJCBS, 3:29-33.

Nworgu, F. C., Ogungbenro, S. A. and Solesi, K. S. (2007). Performance and some blood chemistry indices of broiler chicken served fluted pumpkin (Telefaria occidentalis) leaves extract supplement. American-Eurasian Journal of Agriculture \& Environmental sciencies, 2(1):90-99.

Obikaonu, H. O., Okoli, I. C., Opara, M. N., Okoro, V. M. O., Ogbuewu, I. P., Etuk, E. B., Obun, C. C., Olatunji, E. A and Ukim C. I. (2011). Utilization of sun-cured neem leaf meal (Azadirachta indica. A. juss), Based diets by finisher Broiler chickens. (5): 67-78.

Ogbuewu, I. P., Okoli, I. C. and Iloeje, M. U. (2010). Evaluation of toxicological effects of leaf meal of an ethno medicinal plantneem on blood chemistry of puberal Chinchilla Rabbi 2: 29-34.

Ogbuewu, I. P., Okoli, I.C. and Iloeje, M. U. (2008). Serum biochemical evaluation and organ weight characteristics of buck rabbits fed graded levels Neem (Azadirachta indica) leafmeal diets Veton- line - The International Journal of Veterinary Medicine. (5): $\quad$ 64-75.

Ojha, S., Sonker, K., Pandey, M. and Saraf, S. A. (2011 ). Aloe vera gel: A potent nutraceutical. Journal National Pharm 2:36-39.

Okoli, I. C., Ebere, C. S., Emenalom, O. O., Uchegbu, M. C. and Esonu, B. O. (2001). Indigenous Livestock production paradigms revisited. III: An assessment of the proximate values of most preferred indigenous browses of South Eastern Nigeria. Tropical Animal Production Invest, 4:99-107.

Onyimonyi, A. E., Adeyemi O., and Okeke, G. C., (2009). Performance and Economic Characteristics of Broilers Fed Varying Dietary Levels of Neem Leaf Meal (Azadirachta indica). International Journal of Poultry Science, 8(3) 256-259.

Schalm, O. W., Jain, N. C. and Caroll, E. J., (1975). Veterinary Haematology, 3rd edn. Lea and Febiger, Philadelphia. Pp. $471-538$.

Smith, A. J. (2001). Poultry. The Tropical Agriculture. $2^{\text {nd }}$ (revised) edition. Macmillan education ltd. U.K. Pp. 61-73.

Taylor, D. J. (2001). Effects of antimicrobials and their alternatives. Britain Poultry Science 42:67.

Volger, B. K. and Ernst, E. (2010). “Aloe vera: A Systematic Review of Its Clinical Effectiveness," The British Journal of General Practice, 49(447): 823-828. 